\title{
The Conformity Analysis of English Practicum Courses, English for Midwifery in Midwifery Study Program Faculty of Health Sciences, Alma Ata University, Even Semester, Academic Year 2019/2020
}

\author{
Ika Tri Susilowati \\ Strata 1 of Midwifery Program, Faculty of Health Sciences
}

Chahya Kusuma

Strata 1 of Islamic Education Program, Faculty of Teacher Training and Education Universitas Alma Ata Yogyakarta

\begin{abstract}
It's different from English course, an English practicum course is English for Specific Purpose. In the midwifery study program, an English practicum course is entitled English for Midwifery. This course specifically discusses skills of prospective midwives in handling patients.

This research is a descriptive study with qualitative research method. Data were collected using questionnaire techniques and interviews. The number of respondents in semester II are 12 respondents and semester IV are 22 respondents. Data analysis used the triangulation method by comparing the questionnaire results, interview data and student achievements in the English for Midwifery course.

The results of this study indicate that students who have practiced in the practice field will more easily absorb the material in the English practicum course entitled English for Midwifery. Practical experience in the field provides sufficient background knowledge for students to be more involved in the practical.
\end{abstract}

Keywords: English for midwifery, practice field, background knowledge

\section{INTRODUCTION}

The English practicum course is a practicum hat comes together with the English 2 theory course in the Midwifery program, Faculty of Health Science at Alma Ata University (UAA). The meaning of English practicum here is that students carry out the tasks of the English 2 theory course by using the language of communication, namely English. For example, students have a dialogue with patients, ask about a history of pregnancy, students carry out physical checks with expectant mother who routinely have their health checked at the health center or at a health clinic.

The load of the English practicum course is 1 credit, which means there are 14 meetings with a duration of 100 minutes per 1 meeting.
In 1 meeting, not all skills in English (listening, reading, speaking, writing) were learned by students to be practiced. Usually there are 2 skills learned by students in one practicum, for example, after students listen to conversation in English, then students are asked to complete the imperfect part of conversation. In this meeting students learn listening and writing.

The English practicum course (English 2 of Midwifery) is a continuation of the English course 1.Usually 2 English courses per student in the 4th semester, however, this semester due to curriculum changes causing 2 generations to follow the subject English 2 of Midwifery, namely students in semester 2 and semester 4 students.

This difference in curriculum resulted in 
changes to the courses offered in that semester. Students of $4^{\text {th }}$ semester who get English 2 courses have already received childbirth courses in the third semester and they have practiced in the field for two weeks, while students of $2^{\text {nd }}$ semester have only received pregnancy courses in the second semester. They have not received childbirth courses and they have never practiced in the field.

This difference raises obstacles in the delivery of the material. In addition, because the background knowledge has never experienced direct practice in the field, it also makes students less optimal in carrying out English practicum.

Based on the above problems, the author is interested in conducting research on the suitability analysis of the English practicum course, English for Midwifery in the Midwifery Study Program, Faculty of Health Sciences, Alma Ata University, even semester, academic year 2019/2020.

\section{LITERATURE REVIEW Practicum Courses}

Practicum is a part of teaching that aims to give students the opportunity to test and implement in real situations what is obtained in theory; practical lessons (Poerwadarminta, 2007). Students can directly practice with other students what has been taught in the theory. For example, students can directly practice how to use a tensimeter or sphygmomanometer to measure blood pressure. Students who practice directly will gain experience through direct observation or even do their own experiments with certain objects.

Subiantoro stated that:

Based on the terminology, practicum can be defined as a series of activities that allow a person (student) to apply skills or practice something. In other words, in practicum activities it is possible to apply a variety of science process skills as well as the development of scientific attitudes that support the process of acquiring knowledge (scientific products) in students (Subiantoro, n.d.).
Practicum can develop existing potential in students because in the implementation of practicum students will apply skills in using certain tools or practice something with the help of certain tools.

In learning that applies the practicum method, practicum can be done after the teacher provides directions, cues, instructions for carrying it out (Yamin Martinis, 2013). This means that before doing practicum the teacher will deliver directions assisted by practicum instructions which aim to direct students in carrying out practicum and assisting the teacher in achieve learning goals.

\section{English Practicum}

The English Practicum is a practicum course given in conjunction with the English II theory course. The second English course in the midwifery study program is the ESP (English for Specific Purposes) course, which means that students are equipped with English language skills that are in line with their field of expertise and will be of great benefit to them in their future professions. Such fields of knowledge and professions, for example, English for law, medicine, mechanical engineering, economics, or maritime and so on.

Robinson said "It (here ESP) is generally used to refer to the teaching and learning of a foreign language for a clearly itilitarian purpose of which there is no doubt." (Robinson, 1990)

Meanwhile, Hutchinson and Waters (1994) say that ESP is an approach to teaching English where the things taught and the teaching methods are based on the reasons why the learner wants to learn English. ${ }^{5}$

Thus, teaching English for special purposes (ESP) has a different approach and assumptions from General English (GE), for example. The goal of ESP is for students to be able to master English in the field they are studying. For example chemistry students, then they must understand English for chemistry, or if they are engineering students, they must know English for engineering, or if they work in hospitality, then they must master English for 
hospitality, if they are maritime students, then they must master maritime English.

The English Practicum course focuses on practice, namely practicing all language skills consisting of listening skills, speaking skills, writing skills, and reading skills in one course. The provision of all language skills is intended to equip students to be ready for the world of work after they graduate.

In teaching English practicum, each English lecturer at Alma Ata University uses an interesting method and always innovates so that the learning process is not monotonous and fun so that it can foster student creativity and student motivation in learning English.

\section{RESEARCH METHODS}

This type of this research is descriptive research. The population in this study were all students of the DIII of Midwifery study program, Alma Ata University Yogyakarta, semester 4 and semester 2, academic year 2019/2020.

The data collection technique in this study used a questionaire in the form of an assessment instrument for 28 students. The data analysis technique used by researchers was by assessing student knowledge. The data obtained in this study will be analyzed, according to Arikunto (S, 2006) the assessment uses the following formula:

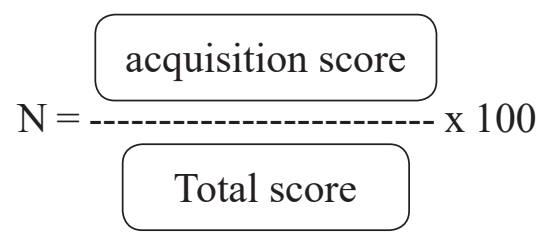

$\mathrm{N}=$ Score

From the formula above, we can check about validity and reliability of an assessment instrument.

An instrument is valid when it is measuring what is supposed to measure (Muijs, 2011). Or, in other words, when an instrument accurately measures any prescribed variable it is considered a valid instrument for that particular variable.

Reliability on the other hand is defined as 'the extent to which test scores are free from measurement error' (Muijs, 2011). It is a measure of stability or internal consistency of an instrument in measuring certain concepts (Jackson, 2003) .

There is a relationship between validity and reliability. Any instrument can be reliable but not valid however, it cannot be valid if it is not reliable [21]. In other words, if an instrument is valid, it must be reliable. And, in general, checking for validity of an instrument is more difficult than checking for reliability because validity is measuring data related to knowledge whereas reliability only concerns with the consistency of scores.

\section{RESULTS AND DISCUSSION}

From the document analysis carried out by the researcher on the results of the student questionnaire, it can be concluded that:

\section{Midwifery student of $4^{\text {th }}$ semester}

All students ( $100 \%$ of students) in $4^{\text {th }}$ semester have directly assessed the problems experienced by expectant mother during early pregnancy. $80 \%$ of students in $4^{\text {th }}$ semester understand the minor disorders of pregnancy faced by expectant mother in early pregnancy, while the other $20 \%$ do not understand the minor disorders of pregnancy faced by expectant mother in early pregnancy. $80 \%$ of students have directly explained to patients about the minor disorder of pregnancy experienced by expectant mother in early pregnancy with preparation or during pregnancy, but $20 \%$ of other students have never explained to patients directly.

As many as $100 \%$ of students (all students) in $4^{\text {th }}$ semester have directly conducted interviews with expectant mother to record a history of pregnancy. All student in $4^{\text {th }}$ semester (100\% students) have also directly conducted physical examinations for pregnant women. Only $20 \%$ of $4^{\text {th }}$ semester students have personally assisted in preparation for the delivery of expectant mother, while $80 \%$ have never helped. $60 \%$ of $4^{\text {th }}$ semester students have provided motivational guidelines for mothers who are about to give birth, but $40 \%$ of other 
students have never provided motivational guidelines for mothers who are giving birth.

Only $13.33 \%$ of $4^{\text {th }}$ semester students have ever guided childbirth and assisted with breathing instructions during childbirth, while $86.66 \%$ of the other students have never guided labor and assisted in breathing instructions during childbirth. $73.33 \%$ of $4^{\text {th }}$ semester students have provided information to patients about recommendations and prohibitions after childbirth, but $26.66 \%$ of other students have never provided information to patients about recommendations and prohibitions after childbirth. As many as $20 \%$ of $4^{\text {th }}$ semester students have helped patients in bathing babies, while $80 \%$ of other students have never helped patients in bathing babies.

There are $46.66 \%$ of $4^{\text {th }}$ semester students who have provided information to patients (new mothers) about what should and should not be done in bathing the baby, while the rest $(53.33 \%)$ other students have never provided information to patients about this. the. The same results were also obtained in the next questionaire, as many as $46.66 \%$ of $4^{\text {th }}$ semester students had helped patients (new mothers) in changing baby diapers, but there were $53.33 \%$ of other students who had never helped patients (mothers who just gave birth). in changing a baby's diaper.

All students $(100 \%$ of students $)$ in $4^{\text {th }}$ semester have already received pregnancy and childbirth course.

\section{Midwife student of $2^{\text {nd }}$ semester}

There are $37.5 \%$ of $2^{\text {nd }}$ semester students who have directly examined the problems experienced by expectant mother at the beginning of pregnancy, but $62.5 \%$ of the others have never directly assessed the problems experienced by expectant mother during early pregnancy. The same results were also obtained in the second questionnaire, that $37.5 \%$ of $2^{\text {nd }}$ semester students understood the minor disorders of pregnancy faced by expectant mother in early pregnancy, while the remaining $62.5 \%$ did not understand the minor disorders of pregnancy faced by expectant mother in early pregnancy. $50 \%$ of $2^{\text {nd }}$ semester students have explained to patients about the minor disorder of pregnancy experienced by expectant mother in early pregnancy with preparation or during pregnancy and $50 \%$ of other, $2^{\text {nd }}$ semester students have never explained this to the patient (pregnant women).

All students (100\%) $2^{\text {nd }}$ semester students have never directly conducted interviews with expectant mother to record their pregnancy history, never directly conducted physical examinations of expectant mother, never directly helped prepare for delivery, and also never guided labor and assisted with instructions exhalation in the labor. Only $12.5 \%$ of students have ever provided motivational guidelines for mothers who are about to give birth, while $87.5 \%$ of other students have never provided motivational guidelines for mothers who are about to give birth.

As much as $37.5 \%$ of $2^{\text {nd }}$ semester students have provided information to patients about recommendations and prohibitions after childbirth, but $62.5 \%$ of other $2^{\text {nd }}$ semester students have never provided information to patients about recommendations and prohibitions after childbirth. $12.5 \%$ of $2^{\text {nd }}$ semester students have helped patients in bathing babies, while $87.5 \%$ of other students have never helped patients in bathing babies. No one of $2^{\text {nd }}$ semester students has ever provided information to a patient (a new mother) about what should and should not be done in bathing a baby.

There are $25 \%$ of $2^{\text {nd }}$ semester students who have helped patients (mothers who just gave birth) in changing baby's diapers, but the other $75 \%$ have never helped patients (mothers who just gave birth) in changing their baby's diapers. All students $(100 \%)$ of $2^{\text {nd }}$ semester students have already taken the "pregnancy" course. $50 \%$ of $2^{\text {nd }}$ semester students have already taken childbirth courses and received both pregnancy \& childbirth courses, but $50 \%$ of other $2^{\text {nd }}$ semester students have not received childbirth courses and they also have not received both pregnancy $\&$ childbirth courses. 
Based on the results of the questionnaire obtained from students in $2^{\text {nd }}$ semester and $4^{\text {th }}$ semester, it was found that the English 2 for Midwifery course was more appropriate for students who had already received pregnancy and childbirth courses. This is evidenced by the final grades of the two semesters.

Table 1: Data on final grades of $2^{\text {nd }}$ semester students

\begin{tabular}{llc}
\hline St. Number & \multicolumn{1}{c}{ Name } & $\begin{array}{c}\text { Final } \\
\text { Grade }\end{array}$ \\
\hline 190200968 & Ajeng Hernita & A \\
190200969 & Amanah Delia Rahma & A \\
190200976 & Eka Purwanti & AB \\
190200970 & Gita Cahaya Fitri & A \\
190200971 & Iqoh Ulil Istianatun Nadhifah & A \\
190200977 & Maya Anisyah Putri & AB \\
190200972 & Nabila Aulia Arindita & A \\
190200973 & Nurdiyanah & B \\
190200974 & Shinta Ayu Faradila & A \\
190200975 & Titin Damayanti & AB \\
190200980 & Yurike Dhea Saputri & AB \\
190200978 & Siti Ratna Sari Potimbang & AB \\
\hline
\end{tabular}

Tabel 2: Data on final grades of $4^{\text {th }}$ semester students

\begin{tabular}{llc}
\hline St. Number & \multicolumn{1}{c}{ Name } & $\begin{array}{c}\text { Final } \\
\text { Grade }\end{array}$ \\
\hline 180200950 & Anggun Tiara Lestari & A \\
180200949 & Amelia Thera Ernanda & A \\
180200951 & Anis Subekti & A \\
180200948 & Ani Rahayu & A \\
180200960 & Novita Lia Rahma One. AP & A \\
180200962 & Salwia & A \\
180200965 & Yesi Setiawati & A \\
180200961 & Rati Bisugi & AB \\
180200955 & Faisa Trisakti & A \\
180200957 & Frida Triastika & A \\
180200947 & Adhelina Firsty Fajrianti & A \\
180200952 & Anugraheni Garly Dumara & A \\
180200963 & Siti Fatonah & A \\
180200967 & Khofifa Turrahmi & A \\
180200953 & Cindy Melanita Putri & A \\
180200956 & Fina Fitriana & A \\
180200958 & Intan Putri Hanifah & A
\end{tabular}

\begin{tabular}{lll}
180200959 & Lutfiah Endang Srilestari & A \\
180200954 & Elvira Vita Auliana & A \\
180200964 & Sri Mulyani & A \\
\hline
\end{tabular}

From the two tables above, the results show that 20 students of $4^{\text {th }}$ semester, there is only 1 student who has an AB grade, while 19 other students in $4^{\text {th }}$ semester get an A grade. If we look at the table of $2^{\text {nd }}$ semester student scores, the results are obtained that of 12 students in $2^{\text {nd }}$ semester, 5 students received an $\mathrm{AB}$ grade while 7 students got an $\mathrm{A}$.

\section{CONCLUSIONS AND SUGGESTIONS Conclusions}

The results of this study indicate that the practical experience of students while in the practical field provides adequate background knowledge and supports the learning process of the student concerned in the English for Midwifery course. This is evidenced by the scores of $4^{\text {th }}$ semester students whose results are better than those of $2^{\text {nd }}$ semester students in these courses.

The results of the questionnaire conducted with the respondents also showed that $70.66 \%$ of the $4^{\text {th }}$ semester students had carried out the activities that were asked based on the questionnaire data, while only $27.5 \%$ of the semester $2^{\text {th }}$ students had carried out the activities that were asked based on the data in the questionnaire.

\section{Suggestions}

English practicum course/ English for midwifery is more appropriate if it is given to students who have taken to the practical field. Students' experiences in practical fields can be valuable background knowledge assets and proven to make it easier for students to understand theory and practice it directly.

Subsequent research can be carried out on the material test or the suitability of RPS English for midwifery if this course cannot be given to students who have taken to the practical field. 


\section{REFERENCES}

Jackson, S. L. (2003). Research Methods and Statistics, A Critical Thinking Approach. Thomson Wadsworth.

Muijs, D. (2011). Doing Quantitative Research in Education with SPSS. SAGE Publications Ltd.

Poerwadarminta, W. J. S. (2007). Kamus Besar Bahasa Indonesia (III, p. 909). Balai Pustaka.

Robinson, P. (1990). English for Specific Purpose. Pergamon Press, Ltd.
S, A. (2006). Prosedur Penelitian: Suatu Pendekatan Praktik. Rineka Cipta.

Subiantoro, A. W. (n.d.). Pentingnya Praktikum dalam Pembelajaran IPA. http://staff. uny.ac.id/sites/default/files/tmp/PPM PENTINGNYA PRAKTIKUM.pdf.

Yamin Martinis. (2013). Desain Pembelajaran Berbasis Tingkat Satuan Pendidikan. Referensi. 